\title{
Pengaruh Kompensasi Terhadap Kinerja Karyawan Pada PT Pancaseraya Permai Di Pekanbaru
}

\author{
AHWANDI; ERFA OKTA LUSSIANDA \\ Sekolah Tinggi Ilmu Ekonomi Persada Bunda \\ Jl. Diponegoro No.42 Pekanbaru \\ ahwandi.1990@gmail.com; erfachianda10@gmail.com
}

\begin{abstract}
This study entitled "The Effect of Compensation Against Employee Performance At PT Pancaseraya Permai Pekanbaru". The problems encountered with the performance of the number of visitors who continue to decline from year to year are also unfair employee compensation. The purpose of this study to determine the effect of compensation on employee performance at PT Pancaseraya Permai Pekanbaru. The population in this research is all employees of PT Pancaseraya Permai Pekanbaru. in 2017 which amounted to 71 people. The sample in this research use saturated sample. Data collection methods used are questionnaires and documentation. Data analysis method used in this research is descriptive and quantitative with test conducted among others simple linear regression analysis, hypothesis test in this research use $t$ test and coefficient of determination. Result of simple linear regression test that is $\mathrm{Y}=35,748+0,723 \mathrm{X}$. Result of $\mathrm{t}$ test can be seen that compensation have significant effect to performance at PT Pancaseraya Permai Pekanbaru. The coefficient of determination obtained is $74 \%$, while the rest is influenced by other variables not examined in this study. Suggestion in this research is Company also suggested not only give compensation but also give high motivation but also can give appreciation, for example award per month or per year to employees with good performance, so it can arouse employee morale and always compete in working for optimal results.
\end{abstract}

Keywords: compensation, performance

Keberadaan sumber daya manusia di dalam suatu perusahaan memegang peranan sangat penting. Tenaga kerja memiliki potensi yang besar untuk menjalankan aktivitas perusahaan. Potensi setiap sumber daya manusia yang ada dalam perusahaan harus dapat dimanfaatkan dengan sebaikbaiknya sehingga mampu memberikan output optimal.

PT Pancaseraya Permai Pekanbaru sebagai salah satu perusahaan pengelola pusat perbelanjaan terkemuka di Pekanbaru yaitu Mall Ciputra Seraya dengan tingkat kompetisi yang tinggi diantara perusahaanperusahaan sejenis perlu meningkatkan kinerja karyawan mereka melalui proses motivasi yang diwujudkan dengan pemberian kompensasi kepada para karyawan mereka yang pada akhirnya nanti diharapkan dengan akumulasi peningkatan kinerja karyawannya. Kompensasi yang diberikan oleh PT Pancaseraya Permai Pekanbaru kepada para karyawannya terbagi dua, yaitu kompensasi finansial dan kompensasi non-finansial. Besar kompensasi berupa gaji, upah dan insentif yang diberikan PT Pancaseraya Permai Pekanbaru kepada para karyawannya pada tahun 2012-2015. Dari tabel dapat dilihat terjadinya fluktuasi pada persentase peningkatan jumlah kompensasi yang diberikan kepada karyawan. Hal ini terjadi dikarenakan jumlah insentif yang berkurang akibat tidak tercapainya target yang diberikan perusahaan. Selain itu juga terjadi pengurangan jumlah karyawan sehingga jumlah kompensasi yang diberikan perusahaan juga menurun.

Hal lain yang ditemukan penulis ketika melakukan observasi adalah masih kurangnya perusahaan memberikan tunjangan seperti uang makan, tunjangan transport, tunjangan komunikasi. Selain itu penulis juga melakukan wawancara dengan beberapa staff administrasi dan mendapatkan keluhan bahwa tidak adanya 
kejelasan dari pihak perusahaan mengenai pengembangan karir, lalu kondisi lingkungan kerja yang kurang kondusif dimana terdapat beberapa karyawan yang suka mencari muka dengan pimpinan atau suka menjelek-jelekan rekan kerjanya.

Ketika proses motivasi yang dilakukan perusahaan kepada karyawan dalam bentuk pemberian kompensasi berjalan dengan lancar dan sesuai dengan perencanaannya maka tahapan selanjutnya yang diharapkan akan terjadi adalah peningkatan kinerja karyawan. Ketika kinerja karyawan telah tercapai maka perusahaan dapat mengukur sejauh mana perkembangan yang mereka capai.

Telah terjadi fluktuasi persentase jumlah pengunjung Mal Ciputra Seraya Pekanbaru. pada tahun 2013 menurun sedangkan pada tahun 2014 dan 2015 meningkat. Dengan jumlah pengunjung yang menurun ini tentu saja mengakibatkan terjadinya penurunan kinerja karyawan.

Hal lain yang peneliti temukan adalah para karyawan tidak memiliki semangat kerja yang baik dimana para karyawan sering terlambat masuk kerja ataupun sering izin kerja tanpa alasan yang jelas. Efisiensi yang kurang dari para karyawan juga terlihat dari karyawan sering berlama-lama jika mendapat tugas keluar kantor.

Berdasarkan latar belakang tersebut mengingat pentingnya kompensasi bagi karyawan, maka penulis tertarik untuk meneliti lebih lanjut dan membahasnya dalam bentuk karya ilmiah atau proposal dengan judul "Pengaruh Kompensasi Terhadap Kinerja Karyawan Pada PT Pancaseraya Permai di Pekanbaru".

Istilah manajemen saat ini sudah sering kita dengar. Manajemen berasal dari kata to manage yang berarti mengendalikan, menangani, atau mengelola. Manajemen merupakan suatu ilmu pengetahuan yang berkembang sekitar abad ke-19. Manajemen menurut Follet dalam Sule dan Saefullah (2010:6) adalah seni menyelesaikan sesuatu melalui orang lain. Segala sesuatu yang perlu dilakukan dalam rangka pencapaian tujuan tertentu. Bagi organisasi bisnis, hal-hal yang harus dilakukan dalam rangka meraih profit antara lain kegiatan produksi, pemasaran, pengelolaan sumber daya manusia hingga pengelolaan keuangan organisasi tersebut. Menurut Terry dalam Sunyoto (2015:2) manajemen adalah melakukan pencapaian tujuan organisasi yang sudah ditentukan sebelumnya dengan mempergunakan bantuan orang lain.

Menurut Sutrisno

manajemen sumber daya manusia mempunyai definisi sebagai suatu perencanaan, pengorganisasian, pengarahan, dan pengawasan atas pengadaan, pengembangan, kompensasi, pengintegrasian, pemeliharaan dan pemutusan hubungan kerja dengan maksud untuk mencapai tujuan organisasi perusahaan secara terpadu.

Sedangkan menurut Ulfatin dan Triwiyanto (2016:3) menyimpulkan bahwa manajemen sumber daya manusia adalah aktivtas untuk mencapai keberhasilan organisasi mencapai tujuan dan berbagai sasarannya serta kemampuan menghadapi tantangan, baik yang bersifat eksternal maupun internal, melalui kebijakan-kebijakan, praktik-praktik, serta sistem-sistem yang mempengaruhi perilaku, sikap, dan kinerja pegawai.

Kompensasi adalah seluruh imbalan yang diterima karyawan atas hasil kerja karyawan tersebut pada organisasi. Kompensasi bisa berupa fisik maupun non fisik dan harus dihitung dan diberikan kepada karyawan sesuai dengan pengorbanan yang telah diberikannya kepada organisasi / perusahaan tempat ia bekerja. Perusahaan dalam memberikan kompensasi kepada para pekerja terlebih dahulu melakukan penghitungan kinerja dengan membuat sistem penilaian kinerja yang adil.

Menurut Mangkuprawira dalam Sunyoto (2015:155) kompensasi merupakan sesuatu yang diterima karyawan sebagai penukar dari kontribusi jasa mereka pada perusahaan. Menurut

p.ISSN: $2407-800 X \quad$ e.ISSN: 2541-4356 
Werther dan Davis dalam Priansa (2014:319) menyatakan bahwa kompensasi merupakan sesuatu yang diterima pegawai sebagai penukar atas kontribusi jasa mereka bagi organisasi.

$$
\text { Menurut Wukir }
$$

kompensasi adalah balas jasa atau imbalan yang diberikan kepada karyawan atas pekerjaan mereka. Perusahaan atau organisasi menggunakan sistem kompensasi sebagai salah satu cara untuk menarik, mempertahankan dan memotivasi karyawan dalam mencapai tujuan organisasi.

Tujuan kompensasi pada tiap-tiap perusahaan berbeda, hal ini tentunya tergantung pada kepentingan perusahaan. Tujuan kompensasi dapat dikatakan sebagai salah satu motivasi atau perangsang yang diberikan oleh perusahaan untuk meningkatkan produktivitas kerja karyawan. Tujuan kompensasi menurut Priansa (2014:325) antara lain: 1) Ikatan kerja sama. Pemberian kompensasi akan menciptakan ikatan kerja sama yang formal antara pengusaha dengan pegawai dalam kerangka organisasi, dimana pengusaha dan pegawai saling membutuhkan; 2) Kepuasan kerja. Pegawai bekerja dengan mengerahkan kemampuan, pengetahuan, keterampilan, waktu, yang semuanya ditujukan bagi pencapaian tujuan organisasi; 3) Pengadaan pegawai. Pengadaan pegawai akan efektif jika dibarengi dengan program kompensasi yang menarik; 4) Motivasi. Kompensasi yang layak akan memberikan rangsangan serta memotivasi pegawai untuk memberikan kinerja terbaik dan menghasilkan produktivitas kerja yang optimal; 5) Menjamin keadilan. Kompensasi yang baik akan menjamin terjadinya keadilan antar pegawai dalam organisasi. Pemberian kompensasi juga berkaitan dengan keadilan internal maupun keadilan eksternal; 6) Disiplin. Pemberian kompensasi yang memadai akan mendorong tingkat kedisiplinan pegawai dalam bekerja. Pegawai akan berperilaku sesuai dengan yang diinginkan organisasi;
7) Pengaruh serikat kerja. Keberadaan organisasi tidak bisa terlepas dari adanya pengaruh serikat buruh dan serikat pegawai. Serikat-serikat tersebut akan mempengaruhi besar kecilnya kompensasi yang diberikan organisasi bagi pegawai; 8) Pengaruh pemerintah. Pemerintah menjamin atas pekerjaan dan penghidupan yang layak bagi pegawai. Untuk itu, melalui kebijakan perundangan dan regulasi, pemerintah mengeluarkan berbagai macam peraturan yang pada intinya untuk melindungi pegawai, sekaligus mendorong investasi dari para pengusaha agar mau menanamkan modalnya.

Jenis-jenis kompensasi menurut Simamora dalam Priansa (2014:322) terdiri dari dua macam yaitu: 1) Kompensasi finansial, kompensasi langsung: Bayaran pokok (base pay), yaitu gaji dan upah, Bayaran prestasi (merit pay, Bayaran insentif (incentive pay) yaitu bonus, komisi, pembagian laba, pembagian keuntungan dan pembagian saham, Bayaran tertangguh (deferred pay) program tabungan, dan anuitas pembelian saham, Kompensasi tidak langsung: Program perlindungan yaitu asuransi kesehatan, asuransi jiwa, pensiun dan asuransi tenaga kerja, Bayaran dari luar jam kerja yaitu liburan, hari besar, cuti tahunan dan cuti hamil, Fasilitas kendaraan, ruang kantor dan tempat parkir; 2) Kompensasi nonfinansial, Pekerjaan: Tugas-tugas yang menarik, tantangan, tanggung jawab, pengakuan dan rasa pencapaian. Lingkungan kerja, Kebijakan yang sehat, supervisi yang kompeten, kerabat kerja yang menyenangkan dan lingkungan kerja yang nyaman.

Faktor-faktor yang mempengaruhi pemberian kompensasi menurut Suwatno dan Priansa (2014:225) adalah sebagai berikut: 1) Produktivitas. Setiap perusahaan pasti menginginkan kinerja keuntungan yang optimal. Keuntungan ini dapat berupa keuntungan material maupun keuntungan non material. Untuk itu,

p.ISSN: $2407-800 \mathrm{X} \quad$ e.ISSN: $2541-4356$ 
setiap perusahaan harus mampu meningkatkan produktivitas kerja karyawannya, agar memberikan kontribusi yang optimal bagi perusahaan. Perusahaan tidak mungkin membayar atau memberikan kompensasi yang melebihi kontribusi atau produktivitas kerja karyawan terhadap perusahaan. 2) Kemampuan untuk membayar. Pemberian kompensasi tergantung kepada kemampuan perusahaan dalam membayar. Perusahaan tdak akan mungkin membayar kompensasi karyawannya melebihi kemampuan perusahaan tersebut dalam memberikan kompensasi. Sebab jika perusahaan memberikan kompensasi diatas kemampuan perusahaan, maka perusahaan itu akan terancam bangkrut. 3) Kesediaan untuk membayar. Kesediaan untuk membayar akan berpengaruh terhadap kebijakan pemberian kompensasi bagi karyawan. Banyak perusahaan yang mampu memberikan kompensasi yang tinggi, tetapi tidak semua perusahaan bersedia memberikan kompensasi yang tinggi. 4) Suplai dan permintaan tenaga kerja. Banyak sedikitnya tenaga kerja di pasar kerja akan mempengaruhi sistem pemberian kompensasi. Bagi karyawan yang tidak memiliki kemampuan dan keterampilan diatas rata-rata tenaga kerja pada umumnya, akan diberikan kompensasi lebih rendah daripada karyawan yang kemampuan dan keterampilannya lebih tinggi. 5) Serikat pekerja. Serikat pekerja, serikat karyawan dan serikat buruh akan mempengaruhi kebijakan pemberian kompensasi. Serikat pekerja biasanya memperjuangkan anggotanya untuk memperoleh kompensasi yang adil, layak serta wajar. Apabila ada perusahaan yang dianggap tidak memberikan kompensasi yang sesuai, maka serikat pekerja akan menuntut perusahaan tersebut. 6) Undangundang dan peraturan yang berlaku. Undang-undang dan peraturan mengenai ketenagakerjaan saat ini mendapatkan sorotan tajam, karena kebijakan tersebut bersentuhan langsung dengan karyawan sebagai salah satu bagian terpenting dalam perusahaan, yang membutuhkan perlindungan. Undang-undang dan peraturan jelas akan mempengaruhi sistem pemberian kompensasi bagi perusahaan. Misalnya UU Tenaga Kerja dan Peraturan UMR.

Menurut Suwanto dan Priansa (2014: 220) asas-asas kompensasi yaitu: Asas Keadilan. Kompensasi mempengaruhi perilaku karyawan dalam organisasi sehingga pemberian kompensasi yang tidak berdasarkan asas keadilan akan mempengaruhi kondisi kerja karyawan. Asas Kelayakan dan kewajaran. Kompensasi yang diterima karyawan harus dapat memenuhi kebutuhan dirinya beserta keluarganya, pada tingkatan yang layak dan wajar, sehingga besaran kompensasi yang akan diberikan akan mencerminkan status, pengakuan, dan tingkat pemenuhan kebutuhan yang akan dinikmati karyawan beserta keluarganya.

Menurut Tua dalam Sunyoto (2015: 159) langkah-langkah untuk menentukan pemberian kompensasi adalah sebagai berikut: Menganalisis jabatan. Analisis jabatan bertujuan untuk mencari informasi tentang tugas-tugas yang dilakukan dan persyaratan yang diperlukan dalam melaksanakan tugas tersebut supaya berhasil untuk mengembangkan uraian tugas, spesifikasi tugas, dan standar untuk kerja. Mengevaluasi jabatan. Merupakan proses sistematis untuk menentukan nilai relative dari suatu pekerjaan dibandingkan dengan pekerjaan lain. Proses ini adalah untuk mengusahakan tercapainya internal equity dalam pekerjaan sebagaimana unsur yang sangat penting dalam penentuan tingkat gaji.

Menurut Bernardin dan Russel dalam Nuraini (2013:150) kinerja cenderung dilihat sebagai hasil dari suatu proses pekerjaan yang pengukurannnya dilakukan dalam kurun waktu tertentu. Menurut Ilgen dan Schneider dalam Nuraini (2013: 50) kinerja adalah suatu proses bagaimana sesuatu dilakukan.

p.ISSN: $2407-800 X \quad$ e.ISSN: 2541-4356 
Menurut Drucker (2013:9) kinerja adalah tingkat prestasi atau hasil nyata yang dicapai dipergunakan untuk memperoleh untuk memperoleh suatu hasil positif. Menurut Amstrong dan Baron dalam Wibowo (2010:7) kinerja merupakan hasil pekerjaan yang mempunyai hubungan kuat dengan tujuan strategis organisasi, kepuasan, konsumen, dan memberikan kontribusi pada ekonomi.

Menurut Handoko (2010: 161) upah merupakan tolak ukur kinerja karyawan. Upah diberikan setelah karyawan menghasilkan kinerja tertentu. Tujuan mengaitkan upah dengan kinerja antara lain sebagai berikut: 1) Upah merupakan bagian dari strategi perusahaan untuk mencapai tujuan perusahaan secara efisien. Skema upah disusun berdasarkan tujuan kinerja., seperti tingkat produktivitas dan keuntungan perusahaan. 2) Untuk mempertahankan dan mengembangkan budaya organisasi dengan merekrut dan mempertahankan retensi karyawan dengan kompetensi tinggi. 3) Menciptakan sistem manajemen SDM denga sistem imbalan intrinsik dan ekstrinsik yang meningkatkan motivasi kerja karyawan. 4) Upah juga berkaitan dengan manajemen kinerja yang mengontrol, mengembangkan, dan mempertahankan kinerja tinggi karyawan.

Kompensasi karyawan merupakan elemen hubungan kerja yang sering menimbulkan masalah dalam hubungan industrial. Masalah kompensasi, khususnya insentif selalu menjadi perhatian manajemen organisasi, karyawan. Kompensasi karyawan menentukan kemampuan perusahaan untuk mendapatkan keuntungan, terutama di perusahaan yang padat karya. Oleh karena itu, jika memungkinkan, manajemen berupaya mengefisiensikan upah karyawan dengan pembayaran minimal, tetapi karyawan harus berkinerja secara maksimal.

Menurut Priansa (2014:325) ketika merekrut seorang karyawan, manajemen organisasi mengharapkan karyawan melakukan pekerjaan atau tugas tertentu untuk mencapai tujuan organisasi. Harapan organisasi dikemukakan dalam bentuk deskripsi tugas (Job description). Jika seorang karyawan menghasilkan kinerja yang diharapkan manajemen, ia akan mendapatkan kompensasi tertentu.

\section{METODE}

Penelitian akan dilaksanakan di PT Pancaseraya Permai Pekanbaru. Populasi dalam penelitian ini adalah karyawan pada PT Pancaseraya Permai Pekanbaru sebanyak 71 orang. Metode yang digunakan dalam penarikan sampel dalam penelitian ini adalah sampel sensus. Menurut Sugiyono (2014:156) sampel sensus adalah teknik penentuan sampel bila semua anggota populasi digunakan sebagai sampel yaitu seluruh karyawan pada PT Pancaseraya Permai Pekanbaru yang berjumlah 71 orang. Teknik analisis data yang digunakan adalah teknik kuantitatif.

\section{HASIL}

Untuk mencari persamaan regresi linear, maka akan dilakukan analisa matematis dengan menggunakan komputer untuk mempermudah pengolahan data yaitu dengan menggunakan program komputer yaitu SPSS (Statistical Product and Secvice Solution) versi 20 for windows evolution. Setelah dilakukan tabulasi terhadap hasil penghitungan masing-masing variabel maka data-data tersebut dimasukkan/diproses kedalam program komputer SPSS versi 20 untuk melihat pengaruh kompensasi terhadap kinerja karyawan PT Pancaseraya Permai sehingga diperoleh hasil seperti table sebagai berikut:

Tabel 1 Hasil Analisis Regresi Linear Sederhana

\begin{tabular}{|l|l|l|l|l|l|}
\hline Model & \multicolumn{2}{|l|}{$\begin{array}{l}\text { Unstandardized } \\
\text { Coefficients }\end{array}$} & $\begin{array}{l}\text { Standardized } \\
\text { Coefficients }\end{array}$ & \multirow{2}{*}{ Sig. } \\
\cline { 2 - 4 } & B & $\begin{array}{l}\text { Std. } \\
\text { Error }\end{array}$ & Beta & & \\
\hline & 35,748 & 5,672 & & 6,302 & 0,000 \\
KOMPENSASI & 0,723 & 0,052 & 0,860 & 14,019 & 0,000 \\
\hline
\end{tabular}

Berdasarkan tabel di atas dapat diketahui persamaan regresi yang terbentuk

p.ISSN: 2407-800X e.ISSN: 2541-4356 
adalah:

$\mathrm{Y}=35,748+0,723 \mathrm{X}$

Dari persamaan tersebut dapat dijelaskan bahwa :

a. Konstanta sebesar 35,748 menyatakan bahwa jika diasumsikan Kompensasi yang diberikan PT Pancaseraya Permai rendah sekali maka Kinerja adalah sebesar 35,748 satuan.

b. Koefisien regresi sebesar 0,723 menyatakan bahwa setiap penambahan satu satuan Kompensasi maka diperkirakan Kinerja mengalami kenaikan sebesar 0,723.

Uji $t$ digunakan untuk menguji pengaruh variabel bebas terhadap variable terikat secara individual. Pengujian hipotesis dilakukan dengan membandingkan nilai $\mathrm{t}$ hitung dengan $t$ tabel pada alpha 5\% dan degree offreedom $(\mathrm{df})=\mathrm{n}-2$ (df) $=71-2=69$

Tabel 2 Hasil Perhitungan Uji t

\begin{tabular}{|l|l|l|l|l|l|}
\hline Model & \multicolumn{2}{|l|}{$\begin{array}{l}\text { Unstandardized } \\
\text { Coeffacients }\end{array}$} & $\begin{array}{l}\text { Standardized } \\
\text { Coefficients }\end{array}$ & \multirow{3}{*}{ Sig. } \\
\cline { 2 - 5 } & $\mathrm{B}$ & $\begin{array}{l}\text { Std. } \\
\text { Error }\end{array}$ & Beta & & \\
& & & & & \\
\hline (Constant) & 35,748 & 5,672 & & 6,302 & 0,000 \\
KOMPENSASI & 0,723 & 0,052 & 0,860 & 14,019 & 0,000 \\
\hline
\end{tabular}

Sumber : Data Olahan SPSS, 2017

Jika nilai $\mathrm{t}$ hitung > t tabel maka hipotesa yang menyatakan bahwa tidak ada pengaruh variabel bebas terhadap variabel terikat akan di tolak artinya variabel bebas berpengaruh secara signifikan terhadap variabel terikat. Sebaliknya jika nilai t hitung $<\mathrm{t}$ tabel maka hipotesis yang menyatakan bahwa tidak ada pengaruh variabel bebas terhadap variabel terikat akan gagal di tolak artinya variabel bebas tidak berpengaruh secara signifikan terhadap variabel terikat.

Nilai t tabel $(\alpha=5 \% ; \mathrm{df}=69)=2.648$

$\mathrm{t}$ hitung $=4,975>\mathrm{t}$ table $=2.648$ Signifikan

Artinya terdapat pengaruh signifikan variabel Kompensasi terhadap variabel Kinerja.

Koefisien determinasi merupakan besaran yang menunjukan besarnya variasi variabel dependen yang dapat dijelaskan oleh variabel independennya. Dengan kata lain, koefisien determinasi ini digunakan untuk mengukur seberapa jauh variabel bebas dalam menerangkan variabel terikatnya. Nilai koefisien determinasi ditentukan dengan nilai $R$ square sebagaimana dapat dilihat pada tabel berikut

Tabel 3 Hasil Perhitungan Koefisien Determinasi ( $R$ Square)

\begin{tabular}{|l|l|l|l|l|}
\hline Mode| & $\mathrm{R}$ & $\begin{array}{l}\mathrm{R} \\
\text { Square }\end{array}$ & Adjusted R Square & $\begin{array}{l}\text { Std. Error of the } \\
\text { Estimate }\end{array}$ \\
\hline 1 & $0,860^{\mathrm{a}}$ & 0,74 & 0,74 & 8,230 \\
\hline
\end{tabular}
Koefisien Determinasi dapat dijelaskan hasil regresi ini memberikan nilai $\mathrm{R}$ Square $=0,74$ artinya $74 \%$ variasi variable Kinerja dijelaskan oleh variasi variabel Kompensasi sedangakan sisanya sebesar $26 \%$ dijelaskan variabel lain.

\section{PEMBAHASAN}

Berdasarkan hasil pengujian secara statistik dengan menggunakan program komputer SPSS versi 20 dapat dilihat bahwa variabel kompensasi mempunyai pengaruh yang searah terhadap kinerja karyawan PT Pancaseraya Permai Pekanbaru artinya semakin baik kompensasi yang diberikan maka akan meningkatkan kinerja karyawan. Hasil tersebut sesuai dengan hipotesis yang diajukan oleh penulis.

Uji reliabilitas menunjukkan bahwa nilai Cronbach Alpha untuk variabel Kompensasi dan Kinerja lebih besar daripada nilai yang ditetapkan para ahli sebesar 0,7 artinya bahwa angket yang berisi indikator dari variabel dinyatakan realibel atau handal. Berdasarkan hasil perhitungan Koefisien Determinasi dapat dijelaskan hasil regresi ini memberikan nilai $\mathrm{R}$ Square $=0,74$ artinya $74 \%$ variasi variable Kinerja dijelaskan oleh variasi variabel Kompensasi sedangakan sisanya sebesar 26\% dijelaskan variabel lain. Secara teori terdapat faktor lain yang dapat mempengaruhi seperti faktor individu yang berkaitan dengan keahlian, motivasi, komitmen dan lain lain, faktor kerja sama yang diberikan rekan kerja, faktor sistem 
yang berkaitan dengan metode kerja serta fasilitas yang disediakan sekolah dan faktor situasi yang berkaitan dengan tekanan baik dari dalam maupun luar lingkungan perusahaan.

Dari hasil pengujian uji t, diperoleh hasil $\mathrm{t}$ hitung sebesar 4,975, jika dibandingkan dengan $\mathrm{t}$ tabel sebesar 1,696 sehingga $t$ hitung lebih besar dari t tabel yang artinya pengaruh kompensasi berpengaruh signifikan terhadap kinerja karyawan pada PT Pancaseraya Permai Pekanbaru. Kompensasi ini diberikan untuk menarik calon tenaga kerja yang berkualitas bergabung dalam perusahaan dan mempertahankan karyawan yang memiliki kinerja yang sangat baik. Hal tersebut dikarenakan dalam pengukuran kinerja dipengaruhi oleh bagaimana karyawan dapat mengerjakan tugasnya baik diukur secara kuantitas, kualitas, kerjasama maupun efisiensi waktu dimana hal tersebut lebih banyak dipengaruhi oleh karayawan itu sendiri secara individual.

Penelitian ini juga mendukung penelitian-penelitian sebelumnya yang menyimpulkan bahwa kompensasi berpengaruh signifikan terhadap kinerja.

\section{SIMPULAN}

Berdasarkan penelitian tentang karyawan pada PT Pancaseraya Permai maka diperoleh kesimpulan sebagai berikut: Kompensasi berpengaruh terhadap kinerja, Peningkatan kompensasi secara merata dapat dilakukan dengan perbaikan kondisi kerja dan aturan seperti menumbuhkan rasa senang bekerja di instansi ini karena bisa mengembangkan keahlian. Selalu berinovasi dan memikirkan perubahan - perubahan yang kreatif terutama dalam persaingan global dan menyongsong era E-Commarce yang sedang dihadapi.

Jika Kompensasi ditingkatkan maka Kinerja akan meningkat. Semakin meningkat kinerja karyawan maka semakin besar kompensasi yang diberikan oleh perusahaan baik kompensasi finansial maupun kompensasi nonfinansial.

\section{DAFTAR RUJUKAN}

Handoko, T. Hani. 2010. Manajemen Personalia \& Sumber Daya Manusia. Yogyakarta: BPFE Fakultas Ekonomika dan Bisinis UGM.

Priansa. 2014. Perencanaan dan Pengembangan SDM. Bandung: Alfabeta

Sunyoto, Danang. 2015. Manajemen dan Pengembangan Sumber Daya Manusia. Jakarta: CAPS (Center for Academic Publishing Service).

Sutrisno, Edy. 2015. Manajemen Sumber Daya Manusia. Jakarta: Kencana Prenadamedia Group.

Suwatno. 2011. Manajemen Sumber Daya Manusia. Bandung: Alfabeta

Suwatno dan Priansa, Donni Juni. 2014. Manajemen SDM dalam Organisasi Publik dan Bisnis. Bandung: Alfabeta.

Ulfatin, Nurul dan Triwiyanto, Teguh. 2016. Manajemen Sumber Daya Manusia Bidang Pendidikan. Jakarta: Raja Grafindo Persada.

Wibowo. 2007. Manajemen Kinerja. Jakarta: Raja Grafindo Persada.

Wukir. 2013. Manajemen Sumber Daya Manusia Dalam Organisasi Sekolah. Yogyakarta: Multi Presindo.

Nuraini. 2013. Manajemen Sumber Daya Manusia. Pekanbaru : Yayasan Aini syam 